
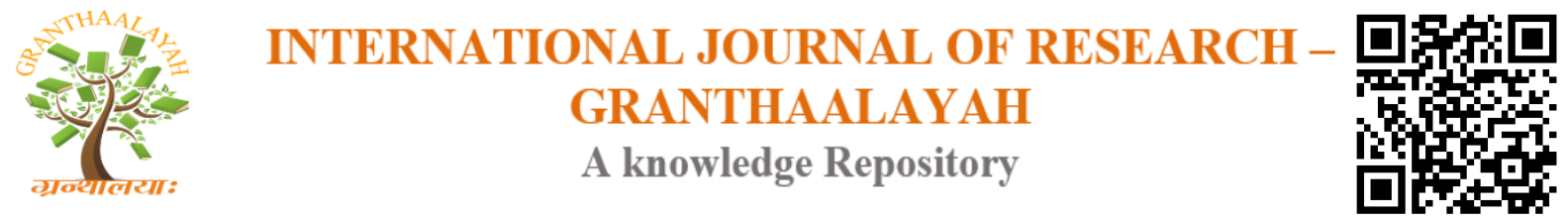

Management

\title{
PERFORMANCE OF REGULATED MARKETS IN TAMIL NADU
}

\author{
Dr. T. Rajendran *1 \\ ${ }^{1}$ Ph. D, Assistant Professor [Agrl. Economics], Tamil Nadu Agricultural University, \\ Agricultural College and Research Institute, Killikulam, Vallanad, Thoothukudi Dist - 628 252, \\ India
}

\begin{abstract}
Analysis of the structure of Regulated Market has shown that there are 19 Regulated Markets under the control of the Tirunelveli Market Committee which are located in Tirunelveli and Thoothukudi districts. Paddy, Chillies and Cotton are the three notified crops. The perceptions of farmers towards Regulated Markets are Large farmers were ignorant of the existence of Regulated Markets and were susceptible to marketing manipulations. Small size of the holdings necessitates the need for providing services of Regulated Markets to ensure better price for their produce.

It is suggested that the growers may be educated regarding the benefits of using the godowns provided by the Market Committee. It is also suggested that the Market Committee may take necessary action for improving the functional efficiency of the Regulated Markets so as to minimize delay in transactions and payments. Farmers feel the disadvantage in the location of market yards, far away from their places of residence. Poor transport facilities between villages and Regulated Markets. The surplus funds of the Market Committee should be utilized for providing loans and advances against the produce of the farmers/traders by which their participation in the Regulated Markets can be improved.
\end{abstract}

Keywords: Regulated Market; Market Committee; Performance; Market Arrivals; Market Surplus.

Cite This Article: Dr. T. Rajendran. (2020). "PERFORMANCE OF REGULATED MARKETS IN TAMIL NADU." International Journal of Research - Granthaalayah, 8(4), 89-94. https://doi.org/10.29121/granthaalayah.v8.i4.2020.11.

\section{Introduction}

Agriculture is the prime profession that helps in the overall development of the economy of Tamil Nadu. Various steps taken by the government to increase the investment in agriculture, agri-based technologies, marketing development, planning approach, etc. have brought substantial improvement in production in spite of seasonal vagaries like flood and drought. Agricultural marketing has become the key driver of the agriculture sector today due to new market realities posed by the increasing accent on globalization, liberalization and privatization of the economy. The Department of Agricultural Marketing functioning since 1977 for regulating agricultural marketing, had been renamed as "Department of Agricultural Marketing and Agri-Business" to 
focus on other latest technologies like post-harvest management, grading, packaging, food processing and export. The core objective of the Department of Agricultural Marketing and AgriBusiness is to help the farmers in marketing their agricultural produce at a fair price and to ensure remunerative returns to them. The aim of this department is regulating agricultural produce trade by enforcing Tamil Nadu Agricultural Produce Marketing (Regulation) Act 1987 most effectively and also implementing new technologies to minimize post-harvest losses by adopting various cost effective post-harvest operations like value addition, storage, grading, packaging, processing, and easy transportation. The Government of Madras enacted the Madras Commercial Crops Market Act in 1933. In order to extend the scope of the Act to all agricultural produces, the Act was modified as Tamil Nadu Agricultural Produce Market Act in 1959. The era of regulated markets started in Tamil Nadu in 1936 with the establishment of the first regulated market for cotton at Tiruppur under the Coimbatore Market Committee. The second regulated market was established at Tindivanam in 1939 under the South Arcot Market Committee.

Regulated markets are functioning under market committees. At present 21 Market committees are functioning in Tamil Nadu at district Level. There are 268 Regulated Markets, 15 Check Posts, 108 Rural Godowns and 108 grading centres functioning under the Market Committees.

Table 1: List of Market Committee in Tamil Nadu

\begin{tabular}{|l|c|c|}
\hline S. No & Market Committees & Number of Markets \\
\hline 1 & Kancheepuram & 14 \\
\hline 2 & Vellore & 12 \\
\hline 3 & Tiruvannamalai & 16 \\
\hline 4 & Cuddalore & 10 \\
\hline 5 & Villupuram & 17 \\
\hline 6 & Salem & 16 \\
\hline 7 & Dharmapuri & 18 \\
\hline 8 & Coimbatore & 24 \\
\hline 9 & Erode & 17 \\
\hline 10 & Tiruchirapalli & 29 \\
\hline 11 & Thanjavur & 10 \\
\hline 12. & Pudukkottai & 21 \\
\hline 13 & Madurai & 20 \\
\hline 14 & Ramanathapuram[Virudhunagar] & 19 \\
\hline 15 & Tirunelveli & 6 \\
\hline 16 & Kanyakumari & - \\
\hline 17 & Theni & - \\
\hline 18 & Dindigul & - \\
\hline 19 & Tiruvarur & $\mathbf{2 6 8}$ \\
\hline & Total & \\
\hline
\end{tabular}

Source: TNAU Agri portal 


\section{Methodology}

From Tirunelveli district based on the convenience sampling three regulated Market was selected viz., Tirunelveli Regulated Market, Sankarankovil Regulated Market and Kovilpatti Regulated Market.

\section{Details of Land Available}

Agricultural marketing is not a simple system but a complex one, which not only involves buying and selling of agricultural produce, but a vast multitude of economic and commercial phenomena, such as assembling, grading, standardization, storage, processing, transportation etc. The main purpose of regulated marketing is to facilitate the farmers a fair deal of marketing by providing market infrastructures and other facilities. All these Infra-structures need adequate land availability. The market yards should be planned according to the site, accessibility, land available and nature of ground. The land owned, total area, area covered by buildings and vacant land available for Tirunelveli Market Committee and for the various regulated markets working under it are furnished in Table 2

Table 2: Locality of Regulated Market

\begin{tabular}{|l|l|l|c|c|c|}
\hline S. No & Regulated Markets & $\begin{array}{l}\text { Own land } \\
\text { / Rented }\end{array}$ & $\begin{array}{c}\text { Total Area } \\
\text { [Acre] }\end{array}$ & $\begin{array}{c}\text { Area covered by } \\
\text { Buildings [Acre] }\end{array}$ & $\begin{array}{c}\text { Available Vacant } \\
\text { Land [Acre] }\end{array}$ \\
\hline 1 & Tirunelveli Market & & & & -- \\
\hline & $\begin{array}{l}\text { Committee Head } \\
\text { Office }\end{array}$ & Own Land & 25 Cents & 25 Cents & \\
\hline & Regulated Markets & & & & 3.23 \\
\hline 1 & Sankarankoil & Own Land & 7.73 & 4.50 & 1.86 \\
\hline 2 & Tirunelveli & Own Land & 4.86 & 3.00 & 0.325 \\
\hline 3 & Kovilpatti & Own Land & 3.02 & 2.70 & - \\
\hline
\end{tabular}

Source: Annual Administration Report, 2018-19

\section{Facilities Available}

One of the objectives of the regulated marketing is to establish market yards with all infrastructure facilities which are designed according to the needs of the volume of business and also in the best interest of the market participants. The need for planned and orderly 'mandi' yards has been felt because of the difficulties experienced in the previous mandi places. The following are the common difficulties or conditions which were or still exist in traditional or unplanned mandies.

- The market place were congested and often located along narrow lanes which do not permit easy access to vehicular traffic. It becomes very difficult for traders to handle their produce and for market committees to supervise transactions.

- The shops were often scattered all over the town and hence the sales and purchases also took place all over the locality.

- Adequate space was not available for exhibiting their produce, its cleaning and grading etc.

- There were no auction platforms. The producer used to sell his produce on the day of its arrival in the market at whatever price.

- There was neither place for parking of carts nor for cattle.

- Facilities like drinking water, public toilets, veterinary dispensary, canteen, rest house etc are not available. 
Similarly, banks and post offices were located away from the place of sale. One of the main objectives of the regulated marketing is to construct a planned market yard where all the facilities of marketing are available. Therefore, from a structural point of view every market is supposed to have a standard layout in which all the market infrastructures are available. The main difficulty in implementation of market regulation was the absence of well-designed market yards having all the requisite facilities since the market committees do not have sufficient funds of their own to develop these market yards. For the development of market yards various financial sources including central government assistance, NABARD, World Bank etc have also been tapped.

\section{Major Commodity arrival in Godowns [Kovilpatti]}

Proper storage facility is a prerequisite for the smooth marketing of agricultural products, Storage facilities are more important in rural areas because farmers are not in a position to store their produce even for a few weeks. With this objective in mind a scheme for the establishment of National grid of Rural Godowns was formulated for creating a network of rural godowns in rural

Table 3: Facilities Available

\begin{tabular}{|l|l|c|c|c|c|}
\hline \multirow{2}{*}{ S. No } & \multirow{2}{*}{ Regulated Markets } & \multicolumn{2}{|c|}{ Godowns } & \multicolumn{2}{|c|}{ Rural Godowns } \\
\cline { 3 - 6 } & & Nos & Capacity M.Tonnes & Nos & Capacity M.Tonnes \\
\hline 1 & Sankarankoil & 1 & 2000 & 1 & 1000 \\
\hline 2 & Tirunelveli & 1 & 2000 & 1 & 1000 \\
\hline 3 & Kovilpatti & 1 & 800 & 1 & 1000 \\
\hline
\end{tabular}

Source: Annual Administration Report, 2018-19

areas to avoid distress sale and to eliminate losses in storage immediately after the harvest when the prices are low. In these godowns a farmer can hold his stock and can sell his produceas and when prices are high. The commodities stored in godowns are Cotton, Pulses, Groundnut, Chillies, Paddy, Cumbu, Maize, Green gram, Ragi and Sunflower.

Table 4: Average Arrival of Commodities

\begin{tabular}{|l|c|c|c|c|c|c|c|c|c|}
\hline Commodity & $\mathbf{2 0 1 2}$ & $\mathbf{2 0 1 3}$ & $\mathbf{2 0 1 4}$ & Average & $\mathbf{2 0 1 5}$ & $\mathbf{2 0 1 6}$ & $\mathbf{2 0 1 7}$ & Average & $\begin{array}{c}\text { Total } \\
\text { Average }\end{array}$ \\
\hline Cotton & 79.05 & 20.7 & 17.508 & 39.086 & 6.575 & 190.86 & 94.36 & 97.265 & 148.84 \\
\hline Pulses & 15.6 & 0 & 0 & 5.2 & 0 & 399.1 & 64.4 & 154.5 & 2871.15 \\
\hline Groundnut & 0 & 1.98 & 1.2 & 1.06 & 0 & 4 & 4.32 & 2.77 & 161.63 \\
\hline Chilli & 379.819 & 26.7 & 0 & 135.50 & 2.52 & 0 & 0 & 0.84 & -99.38 \\
\hline Paddy & 152.18 & 0.13 & 9.1 & 53.80 & 4 & 25 & 3.5 & 10.83 & -79.86 \\
\hline Maize & 1646 & 1840.27 & 3173.25 & 2219.84 & 3157.28 & 2249.12 & 121.2 & 1842.53 & -16.99 \\
\hline Cumbu & 791.48 & 554.3 & 139.3 & 495.02 & 378 & 1152.58 & 215 & 581.86 & 17.54 \\
\hline Green Gram & 0 & 3.6 & 1 & 1.53 & 127 & 12.6 & 7 & 48.86 & 3086.95 \\
\hline Ragi & 753 & 499.73 & 108 & 453.57 & 253.4 & 0 & 0 & 84.46 & -81.37 \\
\hline Sunflower & 0 & 0 & 5.002 & 1.66 & 4.62 & 0 & 0 & 1.54 & -7.63 \\
\hline
\end{tabular}

Source: Annual Administration Report, 2018-19

The result indicate that there was increase in arrival of Cotton (148.84\%), Pulses (2871.15\%), Groundnut (161.63\%), Cumbu (17.54\%), Green Gram (3086.95\%), whereas Paddy (-79.86), Maize (-16.99), Sunflower (-7.63), Chilli (-99.38\%), and Ragi (-81.37\%) arrival was decreased when compared with previous year's average. 
Table 5: Major Commodity Arrival in Godowns in Sankarankovil

\begin{tabular}{|l|c|c|c|c|c|c|c|c|c|}
\hline Commodity & $\mathbf{2 0 1 2}$ & $\mathbf{2 0 1 3}$ & $\mathbf{2 0 1 4}$ & Average & $\mathbf{2 0 1 5}$ & $\mathbf{2 0 1 6}$ & $\mathbf{2 0 1 7}$ & Average & $\begin{array}{c}\text { Total } \\
\text { Average }\end{array}$ \\
\hline Cotton & 6.5 & 87.23 & 39.08 & 44.27 & 256.42 & 20.65 & 42 & 106.35 & 140.24 \\
\hline Pulses & 34.11 & 22.6 & 20.8 & 25.837 & 23.2 & 12.6 & 9.2 & 15 & -41.943 \\
\hline Chilli & 19.32 & 24.5 & 9.6 & 17.80 & 0 & 20.58 & 3.75 & 8.11 & -54.45 \\
\hline Paddy & 1693.68 & 1806.51 & 1208.36 & 1569.51 & 3479.1 & 1137.13 & 1344.19 & 1986.80 & 26.58 \\
\hline Maize & 2301 & 2615.99 & 4888 & 3268.33 & 3710.8 & 1771 & 967 & 2149.6 & -34.22 \\
\hline Gingelly & 17.08 & 12.713 & 3.87 & 11.221 & 2.17 & 38.28 & 5.5 & 15.31 & 36.50 \\
\hline Cholam & 1164.6 & 257 & 0 & 473.86 & 0 & 1976 & 1674 & 1216.66 & 156.75 \\
\hline
\end{tabular}

Source: Annual Administration Report, 2018-19

The results indicates that there was a increase in arrival of commodity like cotton (140.25\%), Paddy (26.58\%), Gingelly (36.5\%), Cholam (156.75\%) whereas there was decreased arrival in case of Pulses (-41.94\%), Chilli (-54.45\%), Maize (-34.22).

Table 6: Major Commodity arrival in Godown in Tirunelveli

\begin{tabular}{|l|c|c|c|c|c|c|c|c|c|}
\hline Commodity & $\mathbf{2 0 1 2}$ & $\mathbf{2 0 1 3}$ & $\mathbf{2 0 1 4}$ & Average & $\mathbf{2 0 1 5}$ & $\mathbf{2 0 1 6}$ & $\mathbf{2 0 1 7}$ & Average & Total Average \\
\hline Cotton & 18.3 & 178.59 & 483.4 & 226.763 & 274.2 & 616.54 & 314 & 401.58 & 77.09 \\
\hline Groundnut & 0 & 11.376 & 0 & 3.792 & 0 & 0 & 56 & 18.66 & 392.26 \\
\hline Cholam & 0 & 0 & 161 & 53.66 & 1500 & 0 & 0 & 500 & 831.67 \\
\hline Paddy & 8436 & 4162.21 & 7995.72 & 6864.64 & 8725.8 & 9220 & 1509.08 & 6484.96 & -5.53 \\
\hline Pulses & 0 & 227.5 & 0 & 75.83 & 0 & 0 & 0 & 0 & -100 \\
\hline
\end{tabular}

Source: Annual Administration Report, 2018-19

There was an increase in arrival of Cotton (77.09\%), Groundnut (392.26\%), Cholam (831.67\%), and decrease in arrival of Paddy (-5.53\%) and Pulse (-100\%).

\section{Summary and Conclusions}

Analysis of the structure of Regulated Market has shown that there are 19 Regulated Markets under the control of the Tirunelveli Market Committee which are located in Tirunelveli and Thoothukudi districts. Paddy, chillies and cotton are the three notified crops. The perceptions of farmers towards Regulated Markets are:

- Large farmers were ignorant of the existence of Regulated Markets and were susceptible to marketing manipulations.

- Small size of the holdings necessitates the need for providing services of Regulated Markets to ensure better price for their produce.

\section{Suggestions to Improve the Effective Functioning of the Regulated Markets are}

- It is suggested that the growers may be educated regarding the benefits of using the godowns provided by the Market Committee.

- It is also suggested that the Market Committee may take necessary action for improving the functional efficiency of the Regulated Markets so as to minimize delay in transactions and payments

- Farmers feel the disadvantage in the location of market yards, far away from their places of residence. Poor transport facilities between villages and Regulated Markets 
- The surplus funds of the Market Committee should be utilized for providing loans and advances against the produce of the farmers/traders by which their participation in the Regulated Markets can be improved.

\section{References}

[1] Annual Administration Report, 2018-19

[2] https://www.tirunelveli.tn.nic.in

[3] District Statistical Handbook, 2018

[4] https://www.tn.gov.in

*Corresponding author.

E-mail address: rajendran.t@ tnau.ac.in 